\title{
Morbidity and mortality of the Critically Endangered Lake Oku clawed frog Xenopus longipes
}

\author{
T. M. Doherty-Bone ${ }^{1,8, *}$, R. K. Ndifon ${ }^{2}$, O. N. Nyingchia ${ }^{2}$, F. E. Landrie ${ }^{3}$, \\ F. T. Yonghabi ${ }^{3}$, A. L. J. Duffus ${ }^{4,9}$, S. Price ${ }^{4}$, M. Perkins ${ }^{4}$, J. Bielby ${ }^{4}$, N. B. Kome ${ }^{5}$, \\ M. LeBreton ${ }^{6}$, L. N. Gonwouo ${ }^{7}$, A. A. Cunningham ${ }^{4}$ \\ ${ }^{1}$ Department of Zoology, Natural History Museum, London SW7 5BD, UK \\ ${ }^{2}$ Oku Fon's Palace, Elak-Oku, North West Region, Cameroon \\ ${ }^{3}$ Belo Rural Development Project, Belo, North West Region, Cameroon \\ ${ }^{4}$ Institute of Zoology, Regents Park, London NW1 4RY, UK \\ ${ }^{5}$ Institute of Agricultural Research for Development, Ekona, South West Province, Cameroon \\ ${ }^{6}$ Global Viral Forecasting Initiative-Cameroon, CRESAR, Yaoundé, Cameroon \\ ${ }^{7}$ Cameroon Herpetology-Conservation Biology Foundation (CAMHERP-CBF), PO Box 8218, Yaoundé, Cameroon \\ ${ }^{8}$ Present address: School of Geography and School of Biology, University of Leeds, Leeds LS2 9JT, UK \\ ${ }^{9}$ Present address: Division of Mathematics and Natural Sciences, Gordon State College, Barnesville, Georgia 30204, USA
}

\begin{abstract}
Between 2006 and 2010, recurring morbidity and mortality of the endemic Lake Oku clawed frog Xenopus longipes was observed at its only known locality, Lake Oku, Cameroon. During repeated visits in 2006, 2008, 2009 and 2010, we found large numbers of dead frogs around the lake shore, as well as a higher than expected prevalence of diseased frogs. No significant relationships between disease occurrence and environmental parameters were found, with the exception of a significant but unexplained association between phosphate concentration and disease incidence. Tissue samples from $X$. longipes collected during 3 field seasons were negative for the amphibian chytrid fungus Batrachochytrium dendrobatidis $(B d)$ using a $B d$-specific real-time PCR test, although other species of sympatric amphibians were positive for this pathogen. Only 1 of 48 tissue samples from diseased frogs was positive for ranavirus infection using a ranavirus-specific PCR, suggesting that this pathogen is not necessarily the cause of this disease. No evidence of pathogens was found in tissues examined histologically from $10 \mathrm{X}$. longipes which had been collected and fixed when freshly dead. The cause(s) of the morbidities and mortalities remain(s) unknown, as does their consequence to the population of this Critically Endangered species. Identifying the causative factor(s) of the $X$. longipes mortality and its impact on the population is crucial for planning conservation actions.
\end{abstract}

KEY WORDS: Amphibian declines $\cdot$ Disease $\cdot$ Limnology $\cdot$ Batrachochytrium dendrobatidis . Ranavirus · Cameroon

\section{INTRODUCTION}

Worldwide, amphibian populations are declining, with approximately a third of all known amphibian species threatened with extinction (Stuart et al. 2004, 2008). Factors associated with this global amphibian decline phenomenon include habitat loss, climate change, infectious disease, overexploitation, pollution and introduced species (as reviewed by Beebee \& Griffiths 2005). Numerous amphibian population declines have been attributed to increased mortality rates following infection with the pathogenic chytrid fungus Batrachochytrium dendrobatidis $\left(B d_{i}\right.$ Lips 1999, Green \& Sherman 2001, Lips et al. 2006). Re- 
cently, mortalities due to infection with another emerging infectious disease of amphibians, ranavirus, have also been shown to cause amphibian population declines (Teacher et al. 2010). When a die-off of an amphibian population is encountered for the first time, it might automatically be assumed that a decline is taking place, but further, often long-term, investigation is needed to determine whether this is the case. The interpretation of investigations into amphibian declines is dependent upon speciesspecific information and requires the teasing apart of causative factors (e.g. distinguishing natural fluctuations from anthropogenic impacts; Pechmann \& Wilbur 1994). Such investigations can be challenging, especially in Africa where many amphibian faunas have been less studied and background data of amphibian population dynamics, habitat requirements and background pathogen presence are lacking (Lawson \& Klemens 2001).

The Lake Oku clawed frog Xenopus longipes (Loumont \& Kobel 1991) is an entirely aquatic frog which is found only in Lake Oku, a crater lake in North West Region, Cameroon. Due to its restricted range and its vulnerability to stochastic factors or the introduction of fish, this species has been classified as Critically Endangered by the IUCN (Stuart et al. 2008). In 2006, several independent observers found dead and diseased $X$. longipes in Lake Oku with consistent signs of limb necrosis or skin ulceration (Figs. 1 \& 2). Such observations had not been made before (i.e. Gartshore 1986, Loumont \& Kobel 1991, Blackburn et al. 2010). Other lakes in this region can undergo limnic eruptions that result from sudden releases of gas, which cause human, fish and livestock mortalities (Kling et al. 1987), and may also have affected frogs in Lake Oku (Blackburn et al. 2010). Changes to the adjacent forest might also be a factor (i.e. Maisels et al. 2000, 2001, BirdLife International 2009). Here, we report the results of investigations to determine the cause and extent of the morbidity and mortality observed and to assess its impact on the $X$. longipes population.

\section{MATERIALS AND METHODS}

\section{Study site}

Lake Oku is situated ca. $2220 \mathrm{~m}$ a.s.l., below the summit of Mount Oku (3011 m a.s.l.), North West Region, Cameroon. This lake is thought to be volcanic in origin, and covers an area of 243 ha with a maximum depth of $52 \mathrm{~m}$ and a mean depth of $32 \mathrm{~m}$

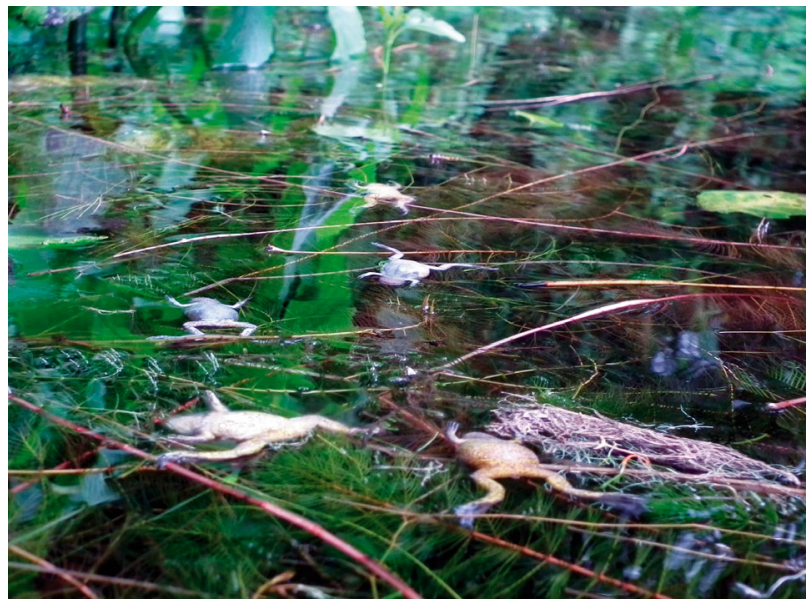

Fig. 1. Xenopus longipes. Dead Lake Oku clawed frogs in Lake Oku, Cameroon, 25 September 2010
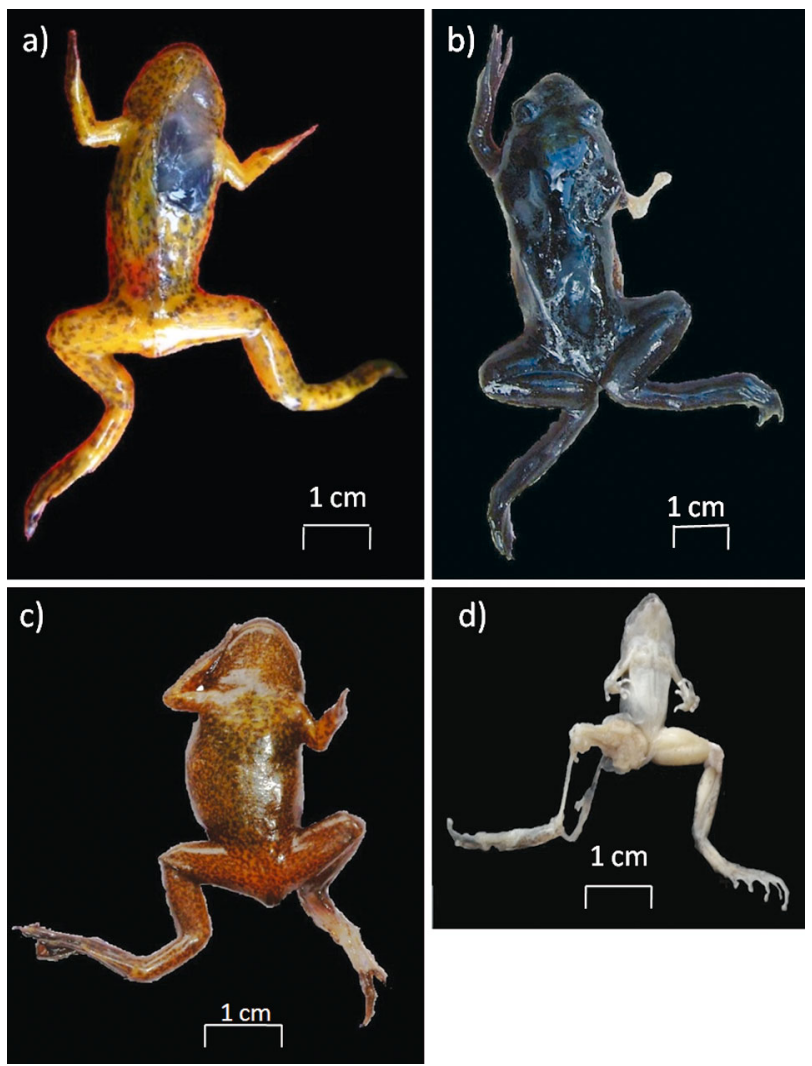

Fig. 2. Xenopus longipes and Phrynobatrachus cf. steindachneri. Diseased frogs found in or near Lake Oku. (a) $X$. longipes found in 2006 with an extensive area of skin ulceration over the ventrum (animal not collected); (b) $X$. longipes specimen no. 5885 collected in 2008 with complete soft tissue loss from the right fore limb; (c) X. longipes specimen XLD5 collected in 2009 with necrosis of the distal left hind limb; (d) specimen no. 4572, a P. cf. steindachneri found dead at a distance from Lake Oku with necrosis of right hind limb 
(Kling 1988); the shoreline is ca. $5.8 \mathrm{~km}$ long (estimated using GoogleEarth 2010). A comparably high Secchi depth (10.9 mi Kling 1988) suggests that this lake is oligotrophic, although there are few published studies on the lake's ecology. Lake Oku is located at the centre of the Kilum-Ijim Forest, a protected community forest. The lake and surrounding forest belt are afforded additional protection as a government 'Plantlife Sanctuary'. The forest around the lake is superficially intact, although many of the larger mammals and at least 1 bird species have been locally extirpated (Maisels et al. 2001). Fuelwood extraction, grazing by livestock and hunting continue to threaten the integrity of the forest (BirdLife International 2009, T. Doherty-Bone, R. K. Ndifon, O. N. Nyingchia pers. obs.). The lake's shore is no more than $1 \mathrm{~km}$ from the forest-farmland boundary, where the land is given over to small-holder agriculture. No fish occur in the lake, although discussions with members of the community have indicated a desire by some parties to stock the lake with fish in an attempt to improve protein intake and the local economy (T. Doherty-Bone, R. K. Ndifon, O. N. Nyingchia pers. obs.). Other amphibians that occur around the lake include Astylosternus ranoides, Cardioglossa oreas, Phrynobatrachus cf. steindachneri and $P$. werneri. The current usage of the lake includes lowlevel tourism as a site of natural beauty, the collection of medicinal plants and for traditional ceremonies by the Oku community. Lake Oku is an important cultural landmark for surrounding communities, especially (but not exclusively) the Oku people, who view the lake as the resting place of their deity, the 'Mawes' (Koloss 2000).

Field work took place at Lake Oku from July to September 2006, October to December 2008 and April to May 2009. An additional, brief visit was made over $3 \mathrm{~d}$ from 25 to 27 September 2010. In 2006, only 1 point of the lake's shore was sampled in order to gather preliminary data. In 2008, 3 study sites $>1 \mathrm{~km}$ apart were established on the lake's shore, and these were revisited in 2009. Local tradition designates abstinence from contact with the lake for $1 \mathrm{~d}$ each week on a rolling $8 \mathrm{~d}$ cycle. This culture was respected, with no field work being conducted at the lake on such days; the lake was otherwise sampled daily during the periods of field work. In each year, the local community was consulted, and their consent obtained, prior to commencing fieldwork.

To minimise the risk of introducing or transferring pathogens, all footwear and equipment were disinfected using bleach between study sites around the lake and prior to visiting or leaving Lake Oku.

\section{Abundance of healthy and sick frogs}

In 2006, frogs were found to be active and abundant during daylight hours. A standardised dip netting survey was designed whereby frogs were captured, marked and recaptured using a net on a ca. $1.2 \mathrm{~m}$ pole, with a mouth diameter of ca. $0.25 \mathrm{~m}$ and a depth of $0.25 \mathrm{~m}$. Four sampling periods took place at 4 to $7 \mathrm{~d}$ intervals over $25 \mathrm{~d}$. Dip netting was conducted between 11:00 and 14:00 $\mathrm{h}$ and consisted of spending 30 min netting as many frogs as possible. Specimens were put into a perforated bucket placed in the lake to prevent desiccation and to avoid recapture within the same sampling period. Captured frogs were marked using a toe clip (on the left hind foot) with a different toe clipped on different dates to differentiate the date of capture so as to determine whether individuals were surviving between sampling periods (following Phillott et al. 2007, Grafe et al. 2011, Perry et al. 2011 and references therein).

In 2008 and 2009, each of the 3 study sites around the lake was sampled alternately for a $3 \mathrm{~d}$ period. Xenopus longipes was far less active during daylight hours than had been the case in 2006, so aquatic funnel traps (unbaited) were used to capture frogs overnight. In 2008, frogs were marked using Alcian Blue dye injected with a Polymedical Dermojet ink injector (Schuco International). As the ink injection was judged to be more traumatic to these small frogs than toe-clipping, frogs captured in 2009 were marked by toe-clipping, using only the right hind foot in order to distinguish them from animals captured in 2006. Toe-clipping has now been exhausted for this population as a mark technique. Only opportunistic observations were made in September 2010. For all field seasons, any observations of dead or sick animals, including scarring (such as that caused by ranavirus; Teacher et al. 2010), both during census work and incidentally were recorded. The number of sick frogs found was noted, as was a description of any obvious lesions or abnormalities. Prevalence observed at each sampling was compared between sample sites and years using Kruskal-Wallis tests. As census techniques differed between 2006 and 2008/09, prevalence between 2008 and 2009 was considered separately using a Mann-Whitney $U$-test.

\section{Environmental parameters}

Rainfall and air temperature were measured daily at base camp ca. $70 \mathrm{~m}$ above Lake Oku at 07:00 h 
from 12 October until 12 November 2008. Wind speed and atmospheric humidity were measured using a thermal hygrometer/anemometer (Atmos Skywatch $\left.{ }^{\circledR}\right)$. At the lake shore, water quality measurements were taken at 09:00 h daily from 12 October until 12 November 2008 (apart from the days when lake access was forbidden for cultural reasons). Measurements comprised water temperature, conductivity, $\mathrm{pH}$ and total dissolved solids and were taken with a Hanna combo meter (model H19129; Hanna Instruments); ammonia from nitrogen, nitrate and phosphate, measured using a portable photometer (Kittiwake SMART II model; Kittiwake Developments); dissolved oxygen, measured using Winkler titrations (Jones et al. 2006); and dissolved carbon dioxide, measured using the titrimetric method (Chapman 1996). The measured parameters were compared amongst the different study sites around the lake (using either 1-way ANOVA or KruskalWallis tests, depending on the normality of data based on a Kolmogorov-Smirnov test).

Associations between daily numbers of observed sick frogs, prevalence of sick frogs and environmental parameters in all study sites were measured individually using bivariate regression analyses. This was restricted to data collected in 2008 when all variables were measured simultaneously. For 1 nutrient (phosphate), an outlier occurred in the regression. As this might have been attributed to an error in the measurement by the photometer, regression analysis both with and without the outlier were considered. Environmental parameters that showed a relationship with actual numbers or prevalence of diseased frogs were subjected to post hoc tests to determine cause and effect. This involved leaving 2 recently discovered dead frogs in each of 3 buckets of water (1.5 l) sourced from Lake Oku, plus 1 additional bucket without dead frogs as a control, for $12 \mathrm{~h}$. After this, the given parameter was measured using the methods described above.

\section{Disease investigations}

Forty-nine toe-clips from marked Xenopus longipes and 25 toe-clips from dead or morbid frogs, all collected in 2006, were fixed in $95 \%$ ethanol in individual Eppendorf microcentrifuge tubes. DNA was extracted from each toe-clip and examined for the presence of $B d$ DNA using real-time quantitative PCR following the protocol of Boyle et al. (2004).

Eleven of these toe-clips were also examined with 10 liver samples from 2008 for the presence of rana- virus DNA using the PCR methods for the major capsid protein of the ranavirus as per Pearman et al. (2004). All primers were sourced from MWG Eurofins Operon (Ebersberg, Germany). PCR reagents were components of the Multiplex PCR kits (Qiagen). All samples were screened twice to ensure the repeatability and accuracy of the results. Since the results of most of the screens were ambiguous, presumably because of the bead-beater extractions used initially for $B d$ screening (which, being intended for fungal cell walls, might have damaged viral DNA), the following additional steps were taken. A $50 \mu \mathrm{l}$ PCR reaction was run out on a gel and extracted using Qiagen Gel Extraction kits. The DNA that was extracted from the gel at the $500 \mathrm{bp}$ level was again amplified by the PCR methods provided by Pearman et al. (2004). A portion of the PCR products were run out on a gel to determine the presence of a band at the $500 \mathrm{bp}$ level which is diagnostic of the presence of ranavirus DNA in the sample. The rest of the samples were sent to be sequenced with the same ranavirus-specific primers. However, due to the low concentration of DNA in the post-gel extraction PCR products, attempts to sequence the DNA present were unsuccessful. A further 27 liver and skin tissue samples (22 from 2008, 5 from 2009, including 2 Phrynobatrachus cf. steindachneri found sick or dead) had DNA extracted using a Biosprint 15 DNA Blood Kit (Qiagen) according to the manufacturer's instructions, and were subjected to PCR assay for ranavirus as described above. To assess whether a different iridiovirus was present, these 27 samples were also subjected to a standard PCR assay for an additional locus (the CARD gene; Ridenhour \& Storfer 2008).

In 2008, 39 apparently healthy Xenopus longipes, collected to initiate a captive assurance colony, were skin-swabbed using MW100 sterile rayon-tipped swabs (Medical Wire \& Equipment) to determine whether they were infected with $B d$. Similarly, the skin of other amphibian species incidentally found or trapped in the immediate locality of Lake Oku was swabbed for the detection of $B d$ infection. Samples were examined for the presence of $B d$ DNA using real-time PCR, as described above (see DohertyBone et al. 2013 for further details).

In 2008 and 2009, frogs found in extremis (28 in 2008, 4 in 2009) were euthanased with an overdose of tricaine methane sulphonate (MS222, Thomson \& Joseph Ltd). The carcasses were then immediately fixed in $95 \%$ aqueous ethanol solution with the body cavity opened to allow the fixative to penetrate the internal organs. A small number of frogs found 
freshly dead (12 in 2008, 6 in 2009) were similarly preserved. All preserved frogs were dissected and their sex determined, and the number of diseased males and females per sample was compared using a Mann-Whitney $U$-test. The skin of the alcohol-fixed animals was sampled in the laboratory for the presence of $B d$ infection using inter-dental brushes, following the methods of Soto-Azat et al. (2009). Ten of the specimens collected in 2008 were systematically dissected and their tissues examined grossly for abnormalities. Limbs affected with areas of necrosis and a section of liver were taken from each of these 10 animals and processed for histological examination using routine methods.

\section{RESULTS}

\section{Abundance of healthy and sick frogs}

The abundance of Xenopus longipes and the numbers of sick and dead $X$. longipes individuals collected during each study visit are presented in Table 1. Diseased animals exhibited abnormal behaviours, such as lethargy, and/or presented with obvious limb or skin lesions, characterised by skin ulceration and limb tissue necrosis, which was often extensive (Fig. 2). No scarring was observed in any of the animals captured. A description of each diseased specimen examined from 2008 to 2009 is presented in Table 2.

Over a 42 d period in 2006, 797 Xenopus longipes were netted, of which 14 were diseased (showed morbidities described above, prevalence $1.8 \%$ ). Over a $32 \mathrm{~d}$ period in 2008, 1283 individuals were trapped, of which 21 were sick (prevalence of $1.6 \%$ ). Thirty of these frogs were recaptures from 2006. In 2009, over an $18 \mathrm{~d}$ period, 254 frogs were captured, of which 3 were sick (prevalence of $1.2 \%$ ). Of these, 2 were individuals recaptured from 2006 and 3 from 2008. There was no significant difference in daily prevalence between all years sampled ( $p>0.05$; Fig. 3 ) or between 2008 and 2009 considered separately where the same census technique was used $(p>0.05)$. We observed 31 dead frogs during the capture effort in 2006, 3 in 2008 and 5 in 2009. In addition, sick and dead frogs were found incidental to the primary capture effort: 7 in 2006, 33 in 2008, 2 in 2009 and 9 in 2010. There was no apparent temporal clustering of diseased animals, with sick and dead frogs observed throughout all field seasons. We detected no significant difference between the abundance of $X$. longipes, the number of sick or dead animals, or prevalence of disease ob- served amongst the 3 sites sampled in 2008 or in 2009. Across the 2008 and 2009 field seasons, we found 19 dead and diseased males (14 in 2008, 5 in 2009), 21 females (17 in 2008, 4 in 2009) and 8 unsexed specimens (including a single tadpole found dead, Table 2). There was no significant difference between the numbers of diseased male or female frogs ( $p>0.05$ ), suggesting no apparent relationship between the gender of frogs and disease.

Amphibians other than Xenopus longipes found and sampled in and around Lake Oku are presented in Table 3. Adult Phrynobatrachus cf. steindachneri and tadpoles of Astylosternus sp. were caught in the funnel traps within Lake Oku, while adult $A$. ranoides were observed in the surrounding forest. A range of post-metamorphic life stages of $P$. cf. steindachneri and $P$. werneri were observed in the forest surrounding the lake. None of these other species showed signs of disease, apart from a single $P$. cf. steindachneri (specimen no. 4572, Table 2, Fig. 2d), which was found in a fish pond at the forest-farm boundary $(<1 \mathrm{~km}$ from the lake shore) with similar signs of limb necrosis to those seen in $X$. longipes. An additional $P$. cf. steindachneri observed near the lake had bleeding hind limbs, and was euthanased as above for further examination (specimen no. 174, Table 2).

\section{Environmental parameters}

Environmental parameters of Lake Oku are summarized in Table 4. No significant differences were found amongst any of the 3 disparate study sites around the lake shore for most of the environmental parameters measured in 2008. The exceptions were: dissolved oxygen $\left(\mathrm{O}_{2}\right)$ (overall mean $\pm \mathrm{SD}$ at $6.01 \pm$ $0.87 \mathrm{ppm}, 5.27 \mathrm{ppm}$ at 1 particular site), conductivity (overall mean of $17.85 \pm 4.17 \mu \mathrm{S}, 21.5 \mu \mathrm{S}$ at 1 site) and total dissolved solids (overall mean $\pm \mathrm{SD}$ of $8.72 \pm$ $2.27 \mathrm{ppm}, 11.67 \mathrm{ppm}$ at 1 site). These differences are small and are therefore not considered to have any biological importance.

We found a significant positive correlation between the number of sick frogs and the abundance of Xenopus longipes, both in $2008(\mathrm{p}<0.05, \mathrm{df}=23)$ and in all field seasons combined (2006-2009; $\mathrm{p}<0.05$, df $=38 ;$ Fig. 4). This relationship was not significant in 2006 or 2009 ( $p>0.05, \mathrm{df}=3 ; \mathrm{p}>0.4, \mathrm{df}=10$, respectively), although this could be due to the relatively smaller sample sizes than in 2008. The concentration of ammonia from nitrogen was positively correlated $(\mathrm{p}<0.05, \mathrm{df}=22)$ with the number of sick $X$. longipes 
Table 1. Xenopus longipes survey data. Overview of sick and dead individuals, abundance and prevalence of disease in Lake Oku, Cameroon, from 2006 to 2009. Dates are given as dd/mm/yyyy. O: incidental observations, where frogs were found either outside a trap or exclusive of dip net survey and were not collected; D: dip net surveys; T: trapping surveys

\begin{tabular}{|c|c|c|c|c|c|c|}
\hline Date & $\begin{array}{l}\text { Census } \\
\text { method }\end{array}$ & No. sick & No. dead & $\begin{array}{l}\text { No. sick } \\
\text { \& dead }\end{array}$ & Abundance & $\begin{array}{l}\text { Daily prevalence } \\
\text { of morbid ind. }\end{array}$ \\
\hline $26 / 07 / 2006$ & $\mathrm{O}$ & 3 & 4 & 7 & & \\
\hline $12 / 08 / 2006$ & $\mathrm{D}$ & 3 & 25 & 28 & 97 & 0.031 \\
\hline 19/08/2006 & $\mathrm{D}$ & 4 & 6 & 10 & 39 & 0.103 \\
\hline 26/08/2006 & $\mathrm{D}$ & 5 & 0 & 5 & 300 & 0.017 \\
\hline 06/09/2006 & $\mathrm{D}$ & 2 & 0 & 2 & 361 & 0.006 \\
\hline 06/09/2008 & $\mathrm{O}$ & 0 & 3 & 3 & & \\
\hline $07 / 10 / 2008$ & $\mathrm{O}$ & 1 & 2 & 3 & & \\
\hline $11 / 10 / 2008$ & $\mathrm{O}$ & 0 & 4 & 4 & & \\
\hline $12 / 10 / 2008$ & $\mathrm{O}$ & 2 & 0 & 2 & & \\
\hline $12 / 10 / 2008$ & $\mathrm{~T}$ & 0 & 1 & 1 & 88 & 0 \\
\hline $13 / 10 / 2008$ & $\mathrm{~T}$ & 1 & 0 & 1 & 82 & 0.012 \\
\hline $14 / 10 / 2008$ & $\mathrm{O}$ & 3 & 1 & 4 & & \\
\hline $14 / 10 / 2008$ & $\mathrm{~T}$ & 1 & 0 & 1 & 95 & 0.011 \\
\hline $15 / 10 / 2008$ & $\mathrm{O}$ & 1 & 6 & 7 & & \\
\hline $15 / 10 / 2008$ & $\mathrm{~T}$ & 1 & 0 & 1 & 107 & 0.009 \\
\hline 18/10/2008 & $\mathrm{O}$ & 0 & 1 & 1 & & \\
\hline $20 / 10 / 2008$ & $\mathrm{O}$ & 1 & 0 & 1 & & \\
\hline $21 / 10 / 2008$ & $\mathrm{O}$ & 0 & 5 & 5 & & \\
\hline $22 / 10 / 2008$ & $\mathrm{~T}$ & 1 & 0 & 1 & 24 & 0.042 \\
\hline $23 / 10 / 2008$ & $\mathrm{~T}$ & 3 & 1 & 4 & 63 & 0.048 \\
\hline $26 / 10 / 2008$ & $\mathrm{~T}$ & 1 & 0 & 1 & 54 & 0.019 \\
\hline $27 / 10 / 2008$ & $\mathrm{~T}$ & 0 & 0 & 0 & 35 & 0 \\
\hline $28 / 10 / 2008$ & $\mathrm{~T}$ & 0 & 0 & 0 & 20 & 0 \\
\hline $29 / 10 / 2008$ & $\mathrm{~T}$ & 4 & 0 & 4 & 163 & 0.025 \\
\hline $30 / 10 / 2008$ & $\mathrm{~T}$ & 0 & 0 & 0 & 157 & 0 \\
\hline $31 / 10 / 2008$ & $\mathrm{~T}$ & 0 & 0 & 0 & 46 & 0 \\
\hline $02 / 11 / 2008$ & $\mathrm{O}$ & 0 & 1 & 1 & & \\
\hline $02 / 11 / 2008$ & $\mathrm{~T}$ & 1 & 0 & 1 & 19 & 0.053 \\
\hline 03/11/2008 & $\mathrm{T}$ & 0 & 0 & 0 & 23 & 0 \\
\hline $04 / 11 / 2008$ & $\mathrm{~T}$ & 0 & 0 & 0 & 15 & 0 \\
\hline $05 / 11 / 2008$ & $\mathrm{~T}$ & 0 & 0 & 0 & 16 & 0 \\
\hline $06 / 11 / 2008$ & $\mathrm{~T}$ & 0 & 0 & 0 & 19 & 0 \\
\hline $07 / 11 / 2008$ & $\mathrm{O}$ & 0 & 1 & 1 & & \\
\hline $07 / 11 / 2008$ & $\mathrm{~T}$ & 0 & 0 & 0 & 27 & 0 \\
\hline 08/11/2008 & $\mathrm{T}$ & 1 & 0 & 1 & 18 & 0.056 \\
\hline $10 / 11 / 2008$ & $\mathrm{~T}$ & 3 & 1 & 4 & 127 & 0.024 \\
\hline $11 / 11 / 2008$ & $\mathrm{~T}$ & 1 & 0 & 1 & 21 & 0.048 \\
\hline $12 / 11 / 2008$ & $\mathrm{~T}$ & 0 & 0 & 0 & 12 & 0 \\
\hline $28 / 11 / 2008$ & $\mathrm{O}$ & 0 & 1 & 1 & & \\
\hline $29 / 11 / 2008$ & $\mathrm{~T}$ & 1 & 0 & 1 & 37 & 0.027 \\
\hline $30 / 11 / 2008$ & $\mathrm{~T}$ & 2 & 0 & 2 & 15 & 0.133 \\
\hline $17 / 04 / 2009$ & $\mathrm{~T}$ & 0 & 0 & 0 & 9 & 0 \\
\hline 01/05/2009 & $\mathrm{T}$ & 0 & 3 & 3 & 16 & 0 \\
\hline $14 / 05 / 2009$ & $\mathrm{~T}$ & 0 & 0 & 0 & 20 & 0 \\
\hline $15 / 05 / 2009$ & $\mathrm{~T}$ & 0 & 0 & 0 & 3 & 0 \\
\hline $16 / 05 / 2009$ & $\mathrm{~T}$ & 1 & 0 & 1 & 36 & 0.028 \\
\hline $17 / 05 / 2009$ & $\mathrm{~T}$ & 2 & 1 & 3 & 32 & 0.063 \\
\hline $23 / 05 / 2009$ & $\mathrm{O}$ & 0 & 1 & 1 & & \\
\hline $24 / 05 / 2009$ & $\mathrm{~T}$ & 0 & 0 & 0 & 14 & 0 \\
\hline $25 / 05 / 2009$ & $\mathrm{~T}$ & 0 & 1 & 1 & 54 & 0 \\
\hline $26 / 05 / 2009$ & $\mathrm{O}$ & 1 & & 1 & & \\
\hline $26 / 05 / 2009$ & $\mathrm{~T}$ & 0 & 0 & 0 & 43 & 0 \\
\hline $27 / 05 / 2009$ & $\mathrm{~T}$ & 0 & 0 & 0 & 10 & 0 \\
\hline $30 / 05 / 2009$ & $\mathrm{~T}$ & 0 & 0 & 0 & 17 & 0 \\
\hline
\end{tabular}


Table 2. Xenopus longipes and Phrynobatrachus cf. steindachneri. Summary of clinical specimens collected in or around Lake Oku from 2008 to 2009. Specimens are X. longipes except where noted. Dates are given as dd/mm/yyyy. O: incidental observations, where a frog was found either outside a trap or exclusive of dip net survey; D: dip net surveys; T: trapping surveys

\begin{tabular}{|c|c|c|c|c|}
\hline Date & $\begin{array}{l}\text { Specimen } \\
\text { code }\end{array}$ & $\begin{array}{l}\text { Live/ } \\
\text { dead }\end{array}$ & Description of morbidity & $\begin{array}{l}\text { Census } \\
\text { method }\end{array}$ \\
\hline 07/10/2008 & BMNH 2008.441 & Dead & No external anomalies recorded; tadpole & $\mathrm{O}$ \\
\hline 07/10/2008 & 5912 & Dead & Necrosis of hind limb & $\mathrm{O}$ \\
\hline 07/10/2008 & 5911 & Dead & Necrosis of integument around the head & $\mathrm{O}$ \\
\hline $11 / 10 / 2008$ & 5910 & Dead & No external anomalies recorded & $\mathrm{O}$ \\
\hline $11 / 10 / 2008$ & 5909 & Dead & Necrosis of fore limbs & $\mathrm{O}$ \\
\hline $12 / 10 / 2008$ & 5885 & Live & Necrosis of fore limbs & $\mathrm{O}$ \\
\hline $12 / 10 / 2008$ & 5884 & Live & Floating upside down, moving when touched & $\mathrm{O}$ \\
\hline $13 / 10 / 2008$ & 5907 & Live & Necrosis of hind limb & $\mathrm{T}$ \\
\hline $14 / 10 / 2008$ & 4590 & Live & Necrosis of hind limb & $\mathrm{O}$ \\
\hline $14 / 10 / 2008$ & 4589 & Live & Necrosis of hind limb & $\mathrm{O}$ \\
\hline $14 / 10 / 2008$ & 4564 & Live & Lethargic behaviour, no other external anomalies & $\mathrm{T}$ \\
\hline $14 / 10 / 2008$ & 4563 & Live & Necrosis of hind limb & $\mathrm{O}$ \\
\hline $14 / 10 / 2008$ & 4562 & Live & Necrosis of both hind limbs & $\mathrm{T}$ \\
\hline $15 / 10 / 2008$ & 5726 & Live & Lethargic, with necrosis of hind limb & $\mathrm{O}$ \\
\hline $15 / 10 / 2008$ & 5725 & Live & Necrosis of both hind limbs & $\mathrm{T}$ \\
\hline $18 / 10 / 2008$ & 5750 & Dead & Necrosis of hind limb & $\mathrm{O}$ \\
\hline 20/10/2008 & 5749 & Live & Completely bloated & $\mathrm{O}$ \\
\hline $22 / 10 / 2008$ & 5748 & Live & Necrosis of fore limb & $\mathrm{T}$ \\
\hline 23/10/2008 & 5747 & Dead & Advanced necrosis of dorsal integument and fore limbs & $\mathrm{T}$ \\
\hline 23/10/2008 & 5746 & Live & Hind limb completely amputated & $\mathrm{T}$ \\
\hline 23/10/2008 & 5745 & Live & Necrosis of hind limb & $\mathrm{T}$ \\
\hline 23/10/2008 & 5727 & Live & Fore limb missing & $\mathrm{T}$ \\
\hline 26/10/2008 & 4565 & Live & Necrosis of hind limb & $\mathrm{T}$ \\
\hline 29/10/2008 & 4571 & Live & Necrosis of hind limb & $\mathrm{T}$ \\
\hline 29/10/2008 & 4570 & Live & Necrosis of hind limb & $\mathrm{T}$ \\
\hline 29/10/2008 & 4569 & Live & Necrosis of hind limb & $\mathrm{T}$ \\
\hline 29/10/2008 & 4568 & Live & Ulcers around head & $\mathrm{T}$ \\
\hline $30 / 10 / 2008$ & 4572 & Dead & $\begin{array}{l}\text { Phrynobatrachus cf. steindachneri with necrosis of hind limb, } \\
\text { in fish pond } 736 \mathrm{~m} \text { from Lake Oku shore }\end{array}$ & $\mathrm{O}$ \\
\hline 02/11/2008 & 5743 & Live & Necrosis of hind limb & $\mathrm{T}$ \\
\hline 02/11/2008 & 5742 & Dead & Advanced stages of necrosis on abdomen and limbs & $\mathrm{O}$ \\
\hline 07/11/2008 & 4573 & Dead & Necrosis of hind limb & $\mathrm{O}$ \\
\hline 08/11/2008 & 4588 & Live & Lethargic, with necrosis of hind limb & $\mathrm{T}$ \\
\hline $10 / 11 / 2008$ & 4585 & Dead & Almost complete necrosis of dorsal integument and hind limb & $\mathrm{T}$ \\
\hline $10 / 11 / 2008$ & 4584 & Live & Necrosis of hind limb & $\mathrm{T}$ \\
\hline $10 / 11 / 2008$ & 4583 & Live & Necrosis of hind limb & $\mathrm{T}$ \\
\hline $10 / 11 / 2008$ & 4582 & Live & Necrosis of hind limb & $\mathrm{T}$ \\
\hline $11 / 11 / 2008$ & 4581 & Live & Necrosis of hind limb & $\mathrm{T}$ \\
\hline 28/11/2008 & 174 & Live & Phrynobatrachus cf. steindachneri, bleeding of hind limbs & $\mathrm{O}$ \\
\hline 28/11/2008 & XL08-1 & Dead & No external anomalies recorded & $\mathrm{O}$ \\
\hline 29/11/2008 & XL08-2 & Live & Necrosis of hind limb & $\mathrm{T}$ \\
\hline $30 / 11 / 2008$ & XL08-3 & Live & Necrosis of hind limb & $\mathrm{T}$ \\
\hline 01/05/2009 & XLD 1 & Dead & No external anomalies recorded & $\mathrm{T}$ \\
\hline 01/05/2009 & XLD 2 & Dead & Hind limb degeneration/necrosis & $\mathrm{T}$ \\
\hline 01/05/2009 & XLD 3 & Dead & Very decomposed & $\mathrm{T}$ \\
\hline 16/05/2009 & XLD 4 & Live & Lesions on front limb with sub-ocular swelling & $\mathrm{T}$ \\
\hline $17 / 05 / 2009$ & XLD 5 & Live & Hind limb degeneration/necrosis & $\mathrm{T}$ \\
\hline $17 / 05 / 2009$ & XLD 6 & Live & Hind limb degeneration/necrosis & $\mathrm{T}$ \\
\hline $17 / 05 / 2009$ & XLD 7 & Dead & Almost complete necrosis of dorsal integument & $\mathrm{T}$ \\
\hline 23/05/2009 & XLD 7a & Dead & No external anomalies recorded & $\mathrm{O}$ \\
\hline 25/05/2009 & XLD 8 & Dead & Necrosis of hind limb & $\mathrm{T}$ \\
\hline 26/05/2009 & XLD 9 & Live & Bloated, with $3+$ hind limbs & $\mathrm{O}$ \\
\hline
\end{tabular}

(Fig. 5). In experimental mesocosms containing dead frogs, the concentration of ammonia from nitrogen increased significantly compared to the control (which did not change over the $12 \mathrm{~h}$ ) from 0 to $0.25 \pm$
$0.2 \mathrm{ppm}$ (mean $\pm \mathrm{SD}$ ) (Fig. 6a). Daily prevalence of sick frogs during 2008 was tested against environmental parameters and was found to be significantly positively correlated only with phosphate concentra- 


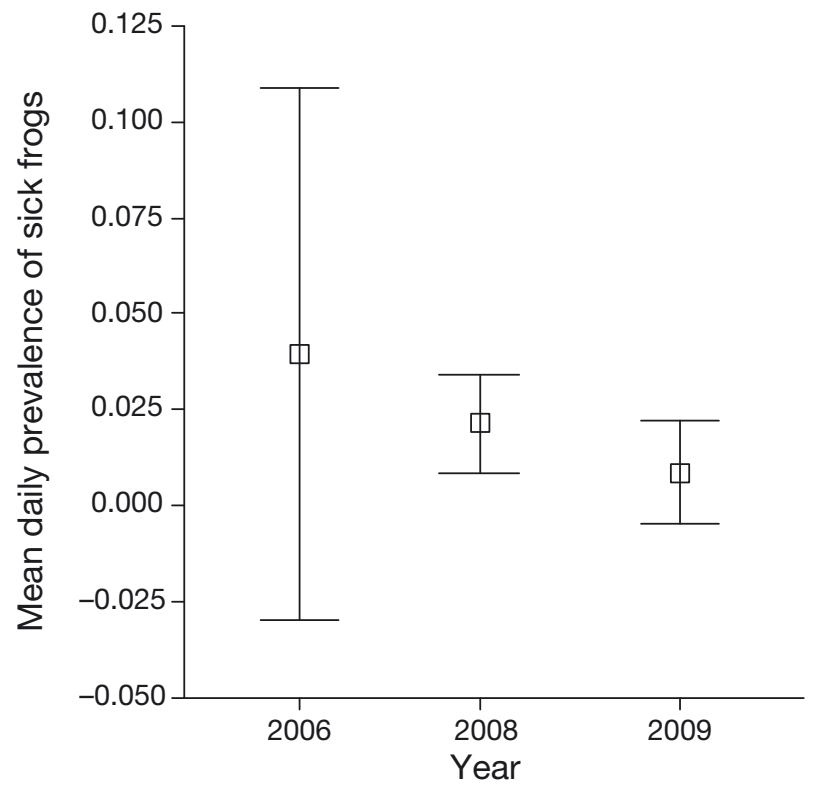

Fig. 3. Xenopus longipes. Mean daily prevalence of sick and dead frogs caught in 2006 (dip net census method), and 2008 and 2009 (aquatic trap census method). Error bars show $95 \%$ confidence interval for the mean

Table 3. Amphibians screened for Batrachochytrium dendrobatidis (chytrid fungus) in the vicinity of Mount Oku, 2008 to 2009 (see Doherty-Bone et al. 2013 for further details)

\begin{tabular}{|c|c|c|}
\hline Species & No. sampled & No. positive \\
\hline \multicolumn{3}{|l|}{2008} \\
\hline Amietophrynus maculatus & 1 & 0 \\
\hline Astylosternus ranoides & 2 & 1 \\
\hline Crotaphatrema lamottei & 5 & 4 \\
\hline Hyperolius riggenbachi & 2 & 2 \\
\hline $\begin{array}{l}\text { Phrynobatrachus cf. } \\
\text { steindachneri }\end{array}$ & 11 & 4 \\
\hline $\begin{array}{l}\text { Phrynobatrachus } \\
\text { steindachneri }\end{array}$ & 8 & 5 \\
\hline Phrynobatrachus werneri & 6 & 4 \\
\hline Trichobatrachus robustus & 1 & 0 \\
\hline Wolterstorffina mirei & 1 & 1 \\
\hline Xenopus amieti & 31 & 10 \\
\hline Xenopus longipes $^{\mathrm{a}}$ & 38 & 0 \\
\hline Xenopus longipes ${ }^{\mathrm{b}}$ & 39 & 0 \\
\hline \multicolumn{3}{|l|}{2009} \\
\hline Astylosternus montanus & 1 & 0 \\
\hline Astylosternus ranoides & 1 & 0 \\
\hline Leptodactylodon perreti & 1 & 0 \\
\hline Ptychadena cf. mascariensis & 2 & 0 \\
\hline Wolterstorffina mirei & 1 & 0 \\
\hline Xenopus longipes $^{\mathrm{a}}$ & 10 & 0 \\
\hline Total no. specimens sampled & 161 & 31 \\
\hline \multicolumn{3}{|c|}{$\begin{array}{l}\text { aEthanol-fixed specimens sampled using the interdental } \\
\text { brush technique } \\
\text { bLive specimens swabbed in captivity }\end{array}$} \\
\hline
\end{tabular}

Table 4. Summary of environmental parameters measured at Lake Oku from 12 October to 12 November 2008

\begin{tabular}{|lcc|}
\hline Parameter & Mean & $\mathrm{SD}$ \\
\hline Water temperature $\left({ }^{\circ} \mathrm{C}\right)$ & 17.27 & 4.17 \\
Air temperature $\left({ }^{\circ} \mathrm{C}\right)$ & 12.77 & 1.13 \\
$\mathrm{pH}$ & 7.58 & 0.24 \\
Conductivity $(\mu \mathrm{S})$ & 17.85 & 4.17 \\
Total dissolved solids $(\mathrm{ppm})$ & 8.72 & 2.27 \\
{$\left[\mathrm{NH}_{3}-\mathrm{N}\right](\mathrm{ppm})$} & 0.30 & 0.3 \\
{$\left[\mathrm{NO}_{3}\right](\mathrm{ppm})$} & 9.48 & 6.9 \\
{$\left[\mathrm{PO}_{4}{ }^{2-}\right](\mathrm{ppm})$} & 2.09 & 2.16 \\
{$\left[\mathrm{O}_{2}\right](\mathrm{ppm})$} & 6.01 & 0.87 \\
{$\left[\mathrm{CO}_{2}\right](\mathrm{ppm})$} & 8.22 & 3.54 \\
$\mathrm{Rainfall}^{(d a i l y ; ~ m m)}$ & 4.29 & 10.93 \\
Wind speed $(\mathrm{km} \mathrm{h}$ & -1 \\
$\mathrm{Humidity}(\%)$ & 7.24 & 4.84 \\
& 97.17 & 5.39 \\
\hline
\end{tabular}
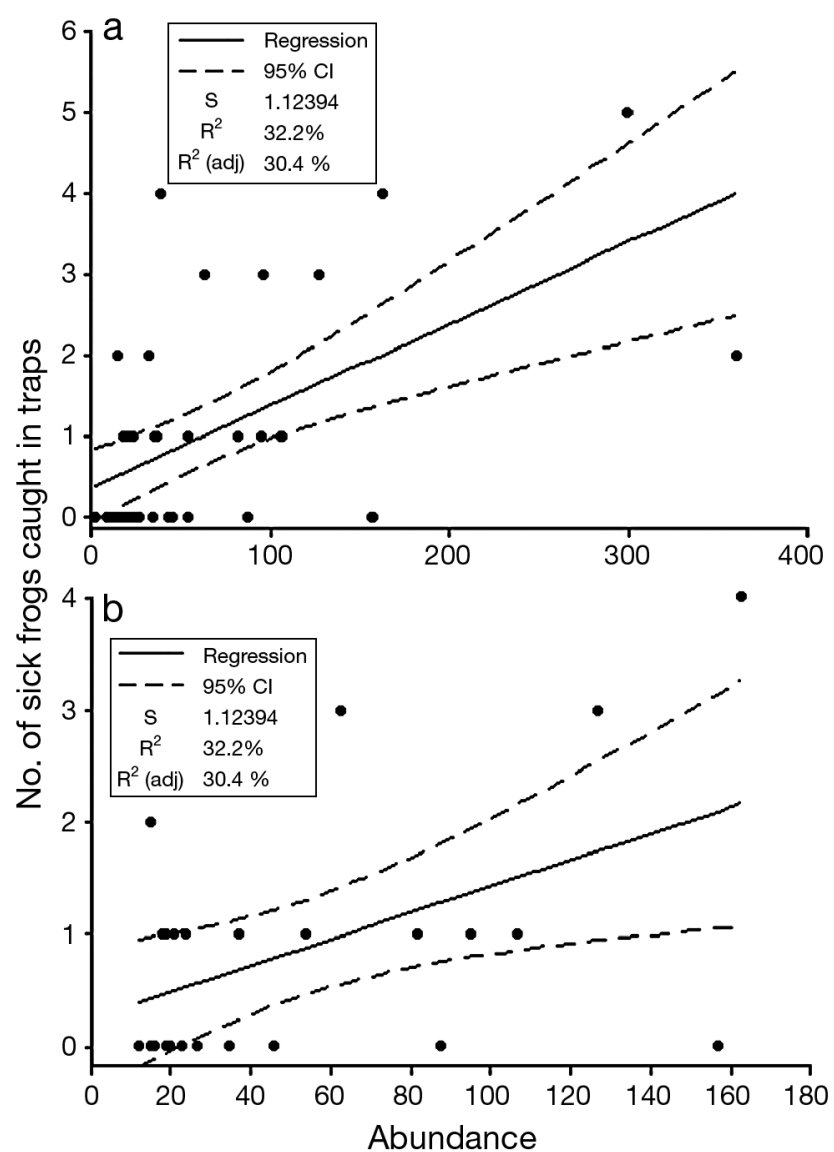

Fig. 4. Xenopus longipes. Correlation (regression, $\mathrm{p}<0.05$ ) between the number of sick frogs caught in traps and the overall abundance of frogs from (a) 2006 to 2009 and (b) October to November 2008. S: square root of mean square error

tion $\left(\mathrm{PO}_{4}{ }^{2-} ; \mathrm{p}<0.0001, \mathrm{df}=22 ; \mathrm{p}<0.05, \mathrm{df}=21\right.$ when a single outlier was removed from the analysis; Fig. 7, Appendix 1). Mesocosm experiments with dead frogs revealed no significant change in phosphate 


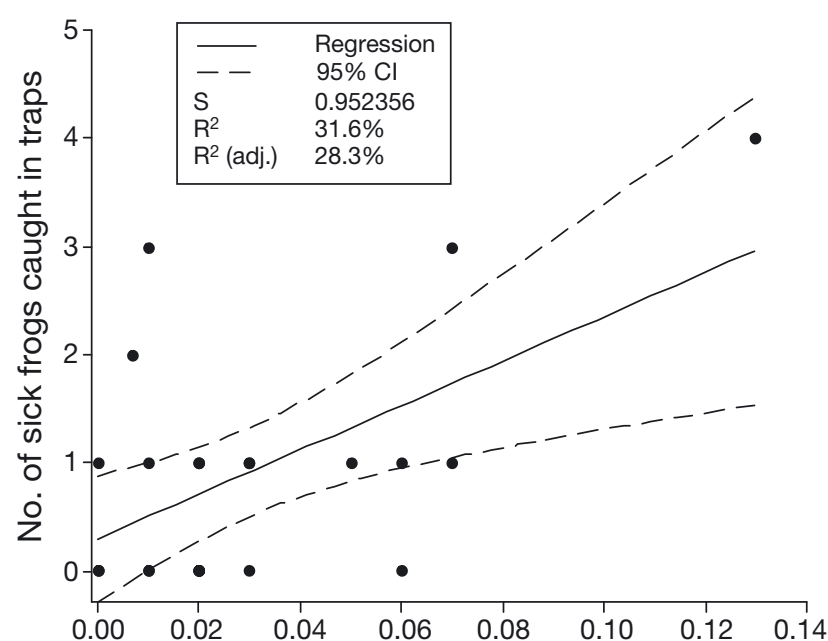

Concentration of dissolved ammoniacal nitrogen (ppm)

Fig. 5. Xenopus longipes. Correlation (regression, p < 0.05) between the number of sick frogs caught in traps in relation to ammoniacal nitrogen $\left(\mathrm{NH}_{3}-\mathrm{N}\right)$ concentration in Lake Oku from October to November 2008

concentration, increasing from $0.81 \pm 0.72$ to $1.01 \pm$ $0.28 \mathrm{ppm}$, compared to the control which also increased to $1.18 \pm 0.32 \mathrm{ppm}$ (Fig. 6b). This suggests that frog mortality does not cause elevated phosphate levels, as opposed to the relationship with ammonia from nitrogen. To account for potential errors from multiple regression, Bonferroni corrections adjusted the significance threshold p-value to 0.0015 . This resulted in only the correlation between prevalence and phosphate including the outlier being significant. There was no sign of forest clearance or agriculture around the edge of the lake to indicate that anthropogenic pollution would be an important factor.

\section{Disease investigations}

One of the 11 toe-clips (sample code XL 59) collected in 2006 showed signs of amplification on the PCR for ranavirus; however, the identity of the amplified DNA could not be confirmed via sequencing. The other 37 ethanol-fixed liver and skin samples collected in 2008 and 2009 were negative for the presence of ranavirus DNA based on diagnostic PCR, including the CARD gene. The numbers of each species skin-swabbed in 2008 and 2009 and tested for the presence of $B d$ infection are presented in Table 3. None of the 87 Xenopus longipes sampled was positive for $B d$ using realtime PCR, although 31 other anurans sampled on
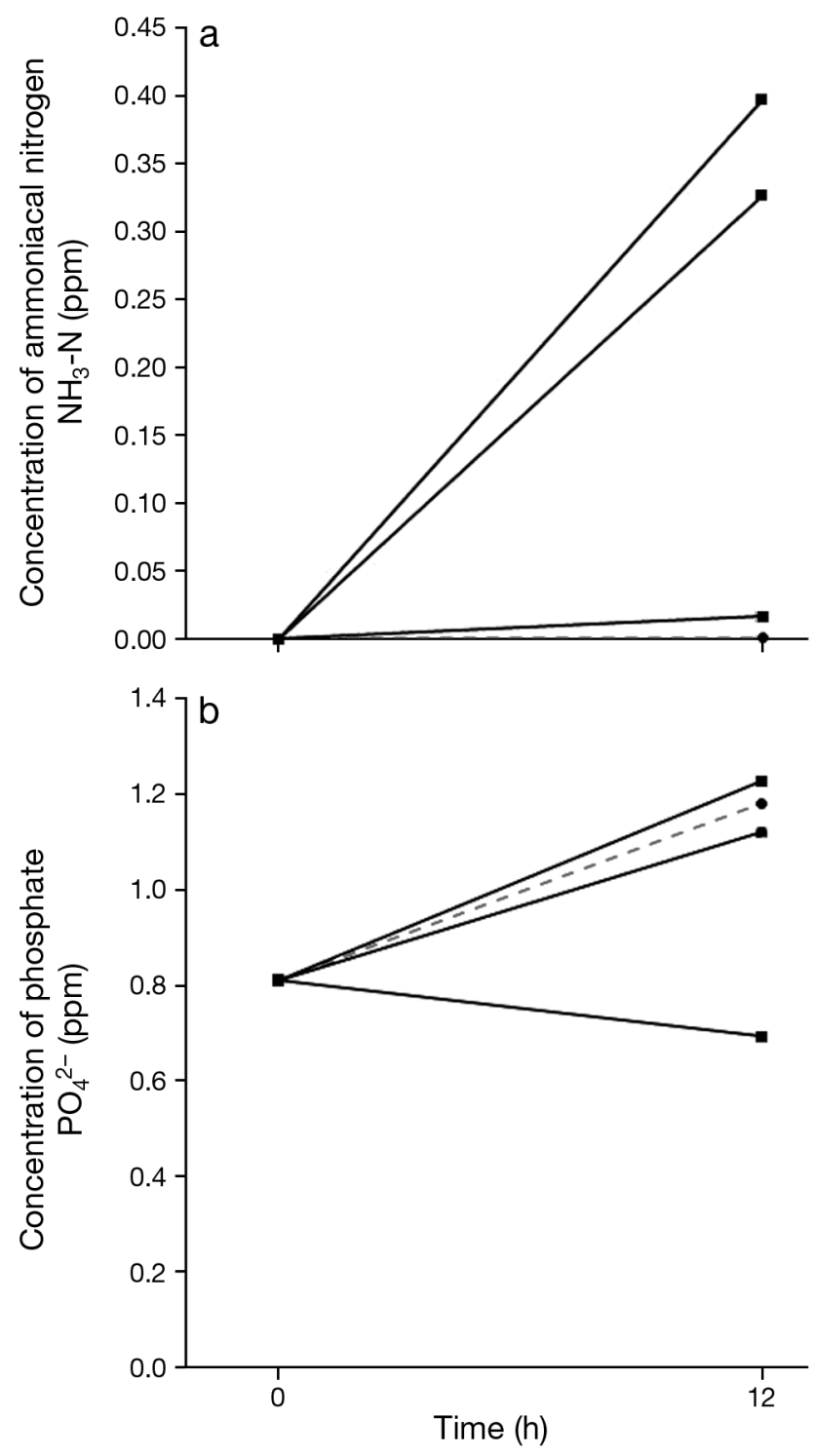

Fig. 6. Xenopus longipes. Effect of dead frogs on (a) ammonia from nitrogen $\left(\mathrm{NH}_{3}-\mathrm{N}\right)$ and $(\mathrm{b})$ phosphate $\left(\mathrm{PO}_{4}{ }^{2-}\right)$ concentration in Lake Oku. Based upon 3 replicates of a mesocosm of water from Lake Oku containing 2 dead $X$. longipes (solid lines and square data points) and a control (grey dashed line with circles) without dead frogs. $0 \mathrm{~h}$ marks the beginning of the experiment, $12 \mathrm{~h}$ its conclusion

Mount Oku were positive (Table 3 ; see DohertyBone et al. 2013).

Gross post-mortem examination of 10 ethanolfixed Xenopus longipes collected in 2008 (specimen codes 4562, 4564, 4565, 4573, 4583, 5748, 5884, 5907, 5911, 5912; Table 2) did not reveal any internal lesions or any abnormalities other than those to the limbs and integument visible at the time of collection. Examination of these animals for $B d$ infection of the 


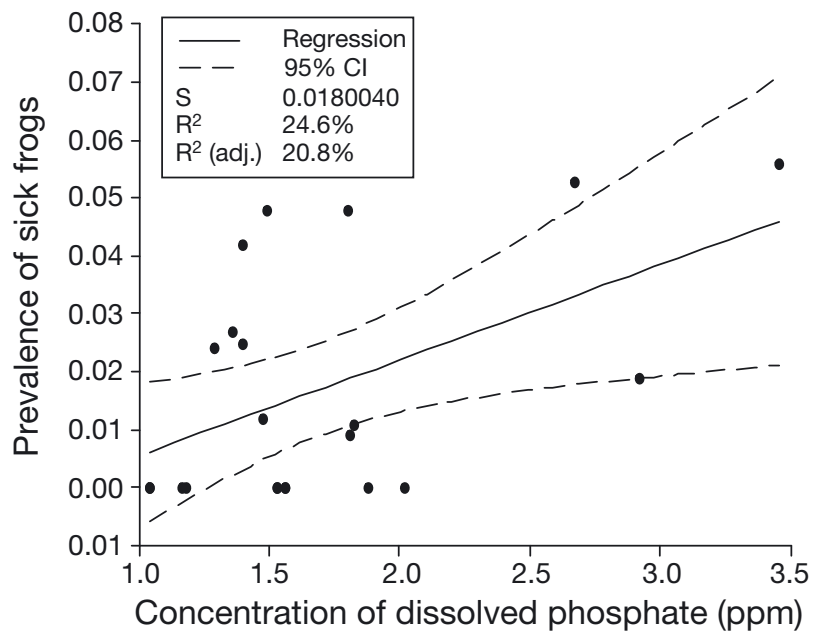

Fig. 7. Xenopus longipes. Fitted line plot showing correlation (regression, $\mathrm{p}<0.05$ ) between the daily prevalence of morbid frogs from trapping effort and dissolved phosphate $\left(\mathrm{PO}_{4}{ }^{2-}\right)$ concentration in Lake Oku from October to November 2008

skin using real-time PCR was negative for the presence of this pathogen. Histological examination of the necrotic or ulcerated areas and the surrounding tissues and of liver sections from these animals failed to identify evidence of pathogens or infectious disease.

\section{DISCUSSION}

The first impression upon seeing sick Xenopus longipes with skin sores and limb necrosis (Fig. 2) was that they were similar to the lesions caused by ranavirus (Cunningham et al. 1996, Teacher et al. 2010) or $B d$ (Bovero et al. 2008) infection in other amphibian species. However, $B d$ was undetected in all $X$. longipes sampled (although it was present in sympatric anuran species), ranavirus was only detected in 1 diseased animal, and histological examination of tissue samples failed to detect evidence of ranaviral disease or chytridiomycosis. There was no evidence in subsequent sampling sessions of individual $X$. longipes having recovered from this disease, such as healed scarring on limbs.

Previously, 26 Xenopus longipes collected in 2006 (Blackburn et al. 2010) and 44 X. longipes collected in 1984 (Soto-Azat et al. 2010) had tested negative for $B d$ infection using pathogen-specific PCR tests. These results support the negative results of previous surveys for $B d$ infection in $X$. longipes and other amphibians in this region (Doherty-Bone et al. 2008,
Blackburn et al. 2010), although $B d$ has been detected in amphibians other than $X$. longipes in Oku and other localities in Cameroon since 2008 (Doherty-Bone et al. 2013). Infection with $B d$ has also been detected in archived Xenopus in the lowlands of eastern Cameroon (Soto-Azat et al. 2010) and, more recently, in multiple anuran species in Nigeria (Imasuen et al. 2011) and Gabon (Bell et al. 2011). The role of this pathogen in the persistence of threatened amphibian populations in Cameroon and Africa in general remains uncertain (Doherty-Bone et al. 2013), although the continued failure to detect $B d$ in $X$. longipes $(\mathrm{n}=231$ negative samples from 3 studies), despite sympatric infected anurans (including congener $X$. amieti, Table 3 ) suggests that this species is resistant to infection by this pathogen.

The positive correlation between Xenopus longipes abundance and the numbers of sick frogs is most likely an autocorrelation, where the probability of observing diseased animals is proportional to the probability of observing any individuals of that species. Abundance is also indicative of activity in $X$. longipes, with entry into traps being a function of frog activity. It may therefore be possible that disease incidence is density dependent, with greater numbers of frogs increasing the transmission rate of a disease agent, although evidence that the observed disease is infectious is still lacking. With the failure to consistently detect DNA of 2 known amphibian pathogens and with no evidence of infection with other, known pathogens on histopathological examination, physical causes of disease need to be considered.

The recorded nitrate concentration in Lake Oku is within the range known to be lethal to certain amphibians (6 North American, 2 European and 1 Australian species; Rouse et al. 1999). Whether or not this concentration of nitrate is unusually elevated for Lake Oku is not known; there was no correlation between nitrate levels and the numbers of sick frogs found. The experiment we conducted showed that the correlation between ammonia from nitrogen and sick frogs was likely explained by the decomposition of dead frogs, although the possibility of densitydependent excretion of ammonia by live frogs was not tested and this might have also contributed to ammonia from nitrogen. The cause of the significant positive correlation of phosphate concentration with prevalence of sick frogs is uncertain, but is shown not to be attributed to decomposition of dead frogs. While phosphate itself is typically not directly lethal to amphibians (Earl \& Whiteman 2010), phosphate concentration in aquatic habitats has been correlated 
with declining immunity and increased infection with parasites in an amphibian population (Lithobates pipiens in North America, Rohr et al. 2008). Variation of exposure of Xenopus longipes to environmental conditions throughout the day is not known, but is likely to occur at least for temperature and should be investigated in future.

In 1985 , temperature $\left(18.6^{\circ} \mathrm{C}\right)$ and dissolved oxygen $\left(7.2 \mathrm{mg} \mathrm{l}^{-1}\right)$ were measured at Lake Oku (Kling 1988), neither of which differed significantly from our 2008 results. Lake Oku still has a thick belt of closed canopy forest surrounding its shore, with no cultivation occurring in the upper catchment. Inputs from agricultural run-off probably do not contribute to its nutrient levels at present, although livestock grazing on the summit of Mount Oku has increased in the past 3 decades (Maisels et al. 2000). The forest surrounding Lake Oku has suffered from degradation for some time, due to the extinction of mammal species from overexploitation (Maisels et al. 2001) and incursions for livestock grazing and fuelwood collection (BirdLife International 2009, T. Doherty-Bone, R. K. Ndifon, O. N. Nyingchia pers. obs.). A road also passes through the forest above Lake Oku, with traffic increasing in recent years (T. Doherty-Bone pers. obs.), which might be a source of pollution. Despite this, there is still much intact forest (a belt $>500 \mathrm{~m}$ ) between the road, grazed areas and Lake Oku. There is no known use of fertilizer in the Lake Oku catchment area (T. Doherty-Bone, R. K. Ndifon, O. N. Nyingchia pers. obs.). Baseline historical concentrations of phosphates and other nutrients in Lake Oku are not available to allow comparisons with the data presented here, so we are unable to ascertain any changes to these over time. This makes it difficult to investigate the apparent link between the prevalence of disease in Xenopus longipes and phosphate concentration in the lake. Continued monitoring of these nutrient levels and of disease incidence will help to assess whether this association is causative. If this is shown to be the case, it will be important to determine the source of phosphate in the lake.

Blackburn et al. (2010) also investigated Xenopus longipes mortality at Lake Oku and similarly failed to identify a causative agent. They hypothesised that the disease was caused by irritation to the skin from sudden changes in the water chemistry of the lake, possibly due to limnic eruptions, i.e. when a large volume of gas (usually carbon dioxide) erupts to the surface of a lake. Such eruptions occurred in Lakes Nyos and Monoun in the same region of Cameroon as Lake Oku (Kling et al. 1987). While no limnic eruptions have been recorded at Lake Oku, there are no settlements in the immediate area of the lake that would ensure detection and reporting. A frequency of wildlife morbidity and mortality caused by limnic eruptions would be expected to be the same as dieoffs shown by fish caused by lake overturn of poisonous gases in Lake Averno, Italy, typified by discrete incidences of dead and dying animals at intervals of 1 to 2 yr (Caliro et al. 2008). The on-going nature of the frog morbidities and mortalities over several years, however, does not support limnic eruptions as a cause.

Other volcanic influences on Lake Oku should be considered as possible causes of the Xenopus longipes disease. We rule out inputs of lava or volcanic gas into the lake, following the same logic as Kling et al. (1987) that the temperature of the lake was far lower than would be expected, never exceeding $18.55^{\circ} \mathrm{C}$. Other possible conditions of volcanic origin in the lake may have been undetected by this study; these include the continuous, chronic release of toxic stressors on the population of $X$. longipes, as is the case for cichlid fishes adapted to the caustic Lake Magadi, Kenya (Narahara et al. 1996). The numbers of sick or dead frogs, however, did not vary significantly with either the level of dissolved carbon dioxide or the $\mathrm{pH}$. Other parameters that could indicate volcanic activity, such as sulphate concentrations, should be measured in future to test this hypothesis. Sampling should also be conducted at different depths and extended to other sections of the lake to assess stratification of these parameters.

The morbidities described here and elsewhere were not recorded or published by researchers who worked at Lake Oku prior to 2006. This could be attributed to low sampling effort whereby morbid animals were not observed due to the collection of unrepresentative sample sizes. For example, Blackburn et al. (2010) visited Lake Oku for an undisclosed (but assumed to be few) number of days in 2003, $2 \mathrm{~d}$ in 2004 and $1 \mathrm{~d}$ in 2006. The expedition which collected the type series for Xenopus longipes spent $2 \mathrm{~d}$ sampling the lake, encountering 58 individuals during 1 night's trapping with none observed incidentally (Loumont \& Kobel 1991). Similarly, an earlier expedition in 1984 spent $6 \mathrm{~d}$ camped above the shore of Lake Oku and captured $51 \mathrm{X}$. longipes by hand over 1 night (Gartshore 1986), with no reports of sick frogs (M. E. Gartshore pers. comm.). Despite Lake Oku being an important component of the Oku and Kom tradition, discussions with members of these communities showed that they were not particularly aware of $X$. longipes in Lake Oku, making traditional local knowledge on this species unavailable. Out of 
48 sampling days, 17 yielded no sick or dead frogs, even on days with over 100 animals captured (Table 1). This suggests that previous, brief, surveys of Lake Oku may not have observed diseased frogs had they been present purely by chance.

Comparisons of mean daily prevalence of sick Xenopus longipes in 2006, 2008 and 2009 showed no significant difference, suggesting that the disease is endemic and not epidemic, contrary to the suggestions of Blackburn et al. (2010). This does not, however, rule out the disease as being novel to $X$. longipes. That so many morbid and dead animals were observed suggests that the level of mortality could be significant at the population level. Such surges in observed numbers of carcasses of wild animals often are indicative of an unusual mortality event, where predators and scavengers have been overwhelmed in consuming these carcasses (Wobeser \& Wobeser 1992). This has held true for other amphibian mortalities, such as die-offs of yellowlegged frogs Rana muscosa and Yosemite toads Bufo canorus in California, USA (Bradford 1991, Green \& Sherman 2001), and incidents of common frog $R$. temporaria mortality in England (Cunningham et al. 1996, Teacher et al. 2010).

Assessing the consequences of these morbidities and mortalities to the population viability of Xenopus longipes is now a priority: the biology of the species, being montane, having a restricted range and an aquatic lifestage, fits with the ecological profile of species suffering serious declines in the near past (Bielby et al. 2008). As sampling took place in disparate seasons using different methods (dip net versus trapping), it was not possible to assess changes in abundance that would control for seasonal fluctuations. Obtaining data on seasonal variation in abundance of $X$. longipes would be useful in contextualising the present data set for future comparisons for this population. We have yet to determine whether a decline has occurred based on between-year markrecapture analyses, although preliminary results show that marked, healthy individuals of $X$. longipes have survived since 2006, with frogs from 2008 surviving to 2009. In each case, however, the number of recaptured animals has been small, explained either by dilution into the large (though vulnerable) population, avoidance of sample sites, mortality of marked animals or all factors combined. A continuation of this capture-mark-recapture study is required to provide robust estimates of survival rates. Use of less invasive and reliable techniques to mark animals is recommended, particularly as the dermo-jet injector is too blunt a tool to note multiple recaptures for $X$. longipes. Toe-clipping on the hind foot has already been exhausted as a marking technique, with clipping of digits on the front-limbs not an option due to likely interference with feeding and mating activities (Grafe et al. 2011).

By surveying the lake on multiple occasions, it was possible to observe a continued and almost stable occurrence of disease in the frog population. We also showed the disease to be present at multiple sites around the lake and not localised at any particular point. Through measuring abundance and capture effort, baseline data for population monitoring has been obtained for Xenopus longipes, so future trends in abundance for this Critically Endangered species can be monitored. Previous observations for $X$. longipes have rarely noted capture effort, making it impossible to assess changes in abundance over time. Our assessment of disease incidence between years, and which was found neither to increase nor decrease significantly between 3 field seasons, also provides data against which future observations can be compared. Also, we found signs of similar disease to that in $X$. longipes affecting Phrynobatrachus cf. steindachneri in the immediate area around Lake Oku.

Despite our investigations, the causes and impacts of the Xenopus longipes disease remain unclear. Similar findings were made by Blackburn et al. (2010), who reported mortalities of $X$. longipes in 2006 independently of our study. Further pathological investigations and further work to determine the biology and ecology of $X$. longipes are required to enable a better understanding of the future prospects for this Critically Endangered amphibian.

Acknowledgements. We thank M. O. Rödel and 2 anonymous reviewers for their useful comments that improved the original manuscript. We thank the Zoological Society of London for providing T.M.D.B. with an Erasmus Darwin Barlow Award. Funding was also provided by the British Ecological Society, the Royal Zoological Society of Scotland, the Percy Sladen Memorial Grant, the University of Aberdeen, the Carnegie Trust for the Universities of Scotland, the Trinity \& Patrick Award from the Royal Geographical Society, the North of England Zoological Society, the Gordon Foundation, the British Herpetological Society, the Explorer's Club of New York and the Institute of Zoology, London. Work in 2006 was facilitated by staff of the Belo Rural Development Project. Thanks are due to D. Ndifon, H. Kolem, R. Miller and K. Peter for assistance in the field. M. Gartshore, D. Blackburn, B. Evans, S. Lötters, B. Moss, L. Connor, D. Gower, S. Loader, H. Meredith and M. Wilkinson shared ideas and provided helpful advice and encouragement. We thank the people of North-West Region for working together with the field team and for making this study possible. This work was carried out under Research Permit nos. 0761, 0928 
and 0697 granted by the Ministry of Forestry and Wildlife, Government of Cameroon. Work was conducted in accordance with institutional, national and international guidelines for the use of animals in research and sampling of endangered species.

\section{LITERATURE CITED}

Beebee TJC, Griffiths RA (2005) The amphibian decline crisis: a watershed for conservation biology? Biol Conserv 125:271-285

Bell RC, Gata Garcia AV, Stuart BL, Zamudio KR (2011) High prevalence of the amphibian chytrid pathogen in Gabon. EcoHealth 8:116-120

Bielby J, Cooper N, Cunningham AA, Garner TJ, Purvis A (2008) Predicting susceptibility to future declines in the world's frogs. Conserv Lett 1:82-90

BirdLife International (2009) Important Bird Area factsheet: Mount Oku, Cameroon. Available at www.birdlife.org (accessed 7 September 2012)

Blackburn DC, Evans BJ, Pessier AP, Vredenburg VT (2010) An enigmatic mortality event in the only population of the Critically Endangered Cameroonian frog Xenopus longipes. Afr J Herpetol 2010:1-12

> Bovero S, Sotgiu G, Angelini C, Doglio S, Gazzaniga E, Cunningham AA, Garner TWJ (2008) Detection of chytridiomycosis caused by Batrachochytrium dendrobatidis in the endangered Sardinian newt Euproctus platycephalus in southern Sardinia, Italy. J Wildl Dis 44:712-715

Boyle DG, Boyle DB, Olsen V, Morgan JAT, Hyatt AD (2004) Rapid quantitative detection of chytridiomycosis (Batrachochytrium dendrobatidis) in amphibian samples using real-time Taqman PCR assay. Dis Aquat Org 60:141-148

Bradford DF (1991) Mass mortality and extinction in a high elevation population of Rana mucosa. J Herpetol 25: 174-177

Caliro S, Chiodini G, Izzo G, Minopoli C, Signorini A, Avino R, Granieri D (2008) Geochemical and biochemical evidence of lake overturn and fish kill at Lake Averno, Italy. J Volcanol Geotherm Res 178:305-316

Chapman DV (1996) Water quality assessments: a guide to the use of biota, sediments and water in environmental monitoring. Spon Press, Taylor \& Francis Groups, London

Cunningham AA, Langton TES, Bennett PM, Lewin JF, Drury SEN, Gough RE, Macgregor SK (1996) Pathological and microbiological findings from incidents of unusual mortality of the common frog (Rana temporaria). Philos Trans R Soc Lond B Biol Sci 351:1539-1557

Doherty-Bone TM, Bielby J, Gonwouo NL, LeBreton M, Cunningham AA (2008) In a vulnerable position? Preliminary survey work fails to detect the amphibian chytrid pathogen in the Highlands of Cameroon, an amphibian hotspot. Herpetol J 18:115-118

> Doherty-Bone TM, Gonwouo NL, Hirschfeld M, Ohst T and others (2013) Batrachochytrium dendrobatidis in amphibians of Cameroon, including first records for caecilians. Dis Aquat Org 102:187-194

Earl JE, Whiteman HH (2010) Evaluation of phosphate toxicity in Cope's gray treefrog (Hyla chrysoscelis) tadpoles. J Herpetol 44:201-208

Gartshore ME (1986) The status of the montane herpetofauna of the Cameroon Highlands. In: Stuart SN (ed) Conservation of Cameroon montane forests. Report of the International Council for Bird Preservation Cameroon Montane Forest Survey. International Council for Bird Preservation, Cambridge, p 204-240

> Grafe TU, Stewart MM, Lampert KP, Rödel MO (2011) Putting toe clipping into perspective: a viable method for marking anurans. J Herpetol 45:28-35

> Green DE, Sherman CK (2001) Diagnostic histological findings in Yosemite toads (Bufo canorus) from a die-off in the 1970s. J Herpetol 35:92-103

Imasuen AA, Aisien MSO, Weldon C, Dalton DL, Kotzem A, du Preez LH (2011) Occurrence of Batrachochytrium dendrobatidis in amphibian populations of Okomu National Park, Nigeria. Herpetol Rev 42:379-382

Jones JC, Reynolds JD, Raffaelli D (2006) Environmental variables. In: Sutherland WJ (ed) Ecological census techniques: a handbook. Cambridge University Press, Cambridge, p 281-316

Kling GW (1988) Comparative transparency, depth of mixing, and stability of stratification in lakes of Cameroon, West Africa. Limnol Oceanogr 33:27-40

Kling GW, Clark MA, Wagner GN, Compton HR and others (1987) The 1986 Lake Nyos gas disaster in Cameroon, West Africa. Science 236:169-175

Koloss HJ (2000) World-view and society in Oku (Cameroon). Dietrich Reimerv, Berlin

Lawson DP, Klemens W (2001) Herpetofauna of the African Rain Forest: overview and recommendations for conservation. In: Weber W, White LJT, Naughton-Treves L (eds) African rainforest ecology and conservation. Yale University Press, New Haven, CT, p 291-307

Lips KR (1999) Mass mortality and population declines of anurans at an upland site in western Panama. Conserv Biol 13:117-125

Lips KR, Brem F, Brenes R, Reeve JD and others (2006) Emerging infectious disease and the loss of biodiversity in a Neotropical amphibian community. Proc Natl Acad Sci USA 103:3165-3170

Loumont C, Kobel HR (1991) Xenopus longipes sp. nov., a new polyploid pipid from western Cameroon. Rev Suisse Zool 98:731-738

Maisels FG, Cheek M, Wild C (2000) Rare plants on Mount Oku summit, Cameroon. Oryx 34:136-140

Maisels F, Keming M, Toh C (2001) The extirpation of large mammals and implications for montane forest conservation: the case of the Kilum-Ijim Forest, North-west Province, Cameroon. Oryx 35:322-331

Narahara A, Bergman HL, Laurent P, Maina JN, Walsh PJ, Wood CM (1996) Respiratory physiology of the Lake Magadi tilapia (Oreochromis alcalicus grahami), a fish adapted to a hot, alkaline and frequently hypoxic environment. Physiol Zool 69:1114-1136

Pearman PB, Garner TWJ, Straub M, Greber UF (2004) Response of the Italian agile frog (Rana latastei) to a Ranavirus, frog virus 3: a model for viral emergence in naïve populations. J Wildl Dis 40:660-669

Pechmann HK, Wilbur HM (1994) Putting amphibian declines into perspective: natural fluctuations and human impacts. Herpetologica 50:65-84

Perry G, Wallace MC, Perry D, Curzer H, Muhlberger P (2011) Toe clipping of amphibians and reptiles: science, ethics, and the law. J Herpetol 45:547-555

Phillott AD, Skerratt LF, McDonald KR, Lemckert FL and others (2007) Toe-clipping as an acceptable method of identifying individual anurans in mark recapture studies. Herpetol Rev 38:305-330 
Ridenhour BJ, Storfer AT (2008) Geographically variable selection in Ambystoma tigrinum virus (Iridoviridae) throughout the western USA. J Evol Biol 21: 1151-1159

Rohr JR, Schotthoefer AM, Rafel TR, Carrick HJ and others (2008) Agrochemicals increase trematode infections in a declining amphibian species. Nature 455: 1235-1239

Rouse JD, Bishop CA, Struger J (1999) Nitrogen pollution: an assessment of its threat to amphibian survival. Environ Health Perspect 107:799-803

Soto-Azat C, Clarke BT, Fisher MC, Walker SF, Cunningham AA (2009) Non-invasive sampling methods for the detection of Batrachochytrium dendrobatidis in archived amphibians. Dis Aquat Org 84:163-166

Soto-Azat C, Clarke BT, Poynton JC, Cunningham AA (2010) Widespread historical presence of Batrachochy- trium dendrobatidis in African pipid frogs. Divers Distrib 16:126-131

Stuart SN, Chanson JS, Cox NA, Young BE, Rodrigues ASL, Fischmann DL, Waller RW (2004) Status and trends of amphibian declines and extinctions worldwide. Science 306:1783-1786

Stuart SN, Hoffmann M, Chanson JS, Cox NA, Berridge RJ, Ramani P, Young BE (eds) (2008) Threatened amphibians of the world. Lynx Edicions, with IUCN - The World Conservation Union, Conservation International and NatureServe, Barcelona

> Teacher AGF, Cunningham AA, Garner TWJ (2010) The impact of Ranavirus infection on wild common frog populations in the UK. Anim Conserv 13:514-522

> Wobeser G, Wobeser AG (1992) Carcass disappearance and estimation of mortality in a simulated die-off of small birds. J Wildl Dis 28:548-554

Appendix 1. Regression analysis of parameters (see Table 4) collected at Lake Oku in 2008. Xl: Xenopus longipes, Ps: Phrynobatrachus cf. steindachneri. S: square root of mean square error; sick frogs: no. of morbid frogs observed; prevalence: proportion of morbid frogs among all frogs sampled. Values in bold are significant $(p<0.05)$

\begin{tabular}{|c|c|c|c|c|c|c|c|c|c|}
\hline Response & Predictor & Coefficient & $\mathrm{SE}$ & $t$ & $\mathrm{~S}$ & $\mathrm{R}^{2}$ & $\begin{array}{c}\mathrm{R}^{2} \text { (adjusted } \\
\text { for ties) }\end{array}$ & $F$ & $\mathrm{p}$ \\
\hline Sick frogs & Abundance of $X I$ & 0.246 & 0.313 & 2.64 & 0.994 & 24.10 & 20.60 & 6.98 & 0.015 \\
\hline Sick frogs & Abundance of $P S$ & 0.050 & 0.072 & 0.70 & 1.128 & 2.20 & 0.00 & 0.48 & 0.494 \\
\hline Sick frogs & Ammoniacal nitrogen $\left(\mathrm{NH}_{3}-\mathrm{N}\right)$ & 20.532 & 6.599 & 3.11 & 0.952 & 31.60 & 28.30 & 9.68 & 0.005 \\
\hline Sick frogs & Nitrate $\left(\mathrm{NO}_{2}\right)$ & -0.012 & 0.032 & -0.38 & 1.147 & 0.70 & 0.00 & 0.14 & 0.710 \\
\hline Sick frogs & Phosphate $\left(\mathrm{PO}_{4}^{2-}\right)$ & 0.108 & 0.104 & 1.04 & 1.123 & 4.90 & 0.30 & 1.07 & 0.312 \\
\hline Sick frogs & Dissolved oxygen $\left(\mathrm{O}_{2}\right)$ & -0.050 & 0.268 & -0.18 & 1.150 & 0.20 & 0.00 & 0.03 & 0.855 \\
\hline Sick frogs & $\mathrm{pH}$ & 0.788 & 1.059 & 0.74 & 1.136 & 2.60 & 0.00 & 0.55 & 0.465 \\
\hline Sick frogs & Conductivity & -0.047 & 0.057 & -0.83 & 1.133 & 3.20 & 0.00 & 0.69 & 0.416 \\
\hline Sick frogs & Water temperature & -0.011 & 0.406 & -0.03 & 1.151 & 0.00 & 0.00 & 0.00 & 0.979 \\
\hline Sick frogs & Total dissolved solids & -0.041 & 0.101 & -0.40 & 1.147 & 0.80 & 0.00 & 0.16 & 0.694 \\
\hline Sick frogs & Dissolved $\mathrm{CO}_{2}$ & -0.161 & 0.103 & -1.56 & 1.178 & 12.50 & 7.40 & 2.43 & 0.137 \\
\hline Sick frogs & Air temperature & -0.039 & 0.219 & -0.18 & 1.167 & 0.20 & 0.00 & 0.03 & 0.861 \\
\hline Sick frogs & Rainfall & -0.022 & 0.022 & -1.00 & 1.153 & 5.00 & 0.00 & 0.99 & 0.331 \\
\hline Sick frogs & Humidity & -0.050 & 0.069 & -0.72 & 1.153 & 2.50 & 0.00 & 0.52 & 0.478 \\
\hline Sick frogs & Wind speed & 0.079 & 0.081 & 0.98 & 1.141 & 4.60 & 0.00 & 0.96 & 0.338 \\
\hline Prevalence & Abundance of $X 1$ & 0.000 & 0.000 & -0.85 & 0.031 & 3.20 & 0.00 & 0.73 & 0.403 \\
\hline Prevalence & Abundance of $P_{S}$ & -0.003 & 0.002 & -1.31 & 0.030 & 7.20 & 3.00 & 1.71 & 0.205 \\
\hline Prevalence & $\mathrm{NH}_{3}-\mathrm{N}$ & -0.073 & 0.221 & -0.33 & 0.032 & 0.50 & 0.00 & 0.11 & 0.744 \\
\hline Prevalence & $\mathrm{NO}_{2}$ & -0.001 & 0.001 & -0.73 & 0.032 & 2.50 & 0.00 & 0.53 & 0.473 \\
\hline Prevalence & $\mathrm{PO}_{4}^{2-}$ & 0.011 & 0.002 & 6.80 & 0.018 & 68.70 & 67.30 & 46.19 & 0.000 \\
\hline Prevalence & $\mathrm{PO}_{4}^{2-}$ (outlier removed) & 0.016 & 0.006 & 2.55 & 0.018 & 24.60 & 20.80 & 6.52 & 0.019 \\
\hline Prevalence & Dissolved $\mathrm{O}_{2}$ & -0.005 & 0.005 & -0.71 & 0.032 & 2.30 & 0.00 & 0.50 & 0.488 \\
\hline Prevalence & $\mathrm{pH}$ & -0.027 & 0.029 & -0.91 & 0.031 & 3.80 & 0.00 & 0.83 & 0.372 \\
\hline Prevalence & Conductivity & -0.001 & 0.002 & -0.39 & 0.032 & 0.70 & 0.00 & 0.15 & 0.703 \\
\hline Prevalence & Water temperature & -0.015 & 0.011 & -1.35 & 0.031 & 8.00 & 3.60 & 1.83 & 0.190 \\
\hline Prevalence & Total dissolved solids & 0.000 & 0.003 & -0.02 & 0.032 & 0.00 & 0.00 & 0.00 & 0.983 \\
\hline Prevalence & Dissolved $\mathrm{CO}_{2}$ & -0.004 & 0.003 & -1.26 & 0.033 & 8.50 & 3.10 & 1.58 & 0.226 \\
\hline Prevalence & Air temperature & -0.002 & 0.004 & -0.40 & 0.021 & 0.80 & 0.00 & 0.16 & 0.694 \\
\hline Prevalence & Rainfall & 0.000 & 0.000 & -1.18 & 0.020 & 6.80 & 1.90 & 1.39 & 0.253 \\
\hline Prevalence & Humidity & -0.001 & 0.001 & -0.88 & 0.021 & 3.70 & 0.00 & 0.77 & 0.389 \\
\hline Prevalence & Wind speed & 0.000 & 0.001 & 0.10 & 0.021 & 0.10 & 0.00 & 0.01 & 0.919 \\
\hline
\end{tabular}

Editorial responsibility: Michael Mahony, Callaghan, New South Wales, Australia
Submitted: December 11, 2012; Accepted: April 27, 2013 Proofs received from author(s): July 19, 2013 